INTERNATIONAL JOURN AL OF RESEARCHES IN BIOSCIENCES, AGRICULTURE AND TECHNOLOGY (c) VISHWASHANTI MULTIPURPOSE SOCIETY (Global Peace Multipurpose Socie ty) R. No. MH-659/13 (N) www.vmsindia.org

\title{
STUDIES ON ANTAGONISTIC ACTINOMYCETES FROM CASUARINA EQUISELIFOLIA L.
}

\author{
Sangita Kulkarni ${ }^{1}$ and Abhijit Kulkarni ${ }^{2}$ \\ ${ }^{1}$ Radhabai Kale Mahila Mahavidyalaya, Ahmednagar (MS) \\ 2Departme nt of Botany, Ahmednagar College, Ahmednagar (MS) \\ sangitakulkarni69@gmail.com
}

\begin{abstract}
:
The Rhizosphere soils are rich in microflora. A number of Actinomycetes were found associated with rhizos phere soils of Casuarina plants. A total of 20 different actinomycetes were isolated from the rhizosphere soil of Casuarina equisetifolia L. from different localities of Maharashtra. These included 14 species of Streptomyces ${ }_{2}$ four species of Streptoverticillium and two unidentified Actinomycetes species. The Actinomycetes are rich source of antibiotics. The isolates were tested for their antagonistic properties against phyto-pathogenic and human pathogenic bacteria and fungi. Streptomyces chattanoogensis \& Streptomyces violaceochromogenes inhibited the growth of Bacillus subtilis while Streptomyces violaceochramogenes, Streptoverticillium fervens and Actinomyce te (1) were antagonistic to all phyto-pathogenic fungi. These experiments clearly indicated that actinomycetes isolated from rhizosphere of Casuarina equiselifolia L. show antagonism against the soil pathogens

Keywords: Actinomycetes, Strepto myces, Antagonism.
\end{abstract}

\section{Introduction}

The Rhizosphere soils are near to the plant roots and is rich in microflora. The Actinomycetes are one of group of microorganisms that are beneficial in nature and source of many antibiotics which are active against pathogenic organisms (Abhijit kulkarni, 2010). The antibiotic compounds are useful as human \& veterinary medicine, in agriculture \& biochemistry. It is a transitional group between simple bacteria $\&$ Fungi. They are gram positive $\&$ are classified under the order Actinomycetales (Bergy's Manual,1989). Most of Microbial equilibrium is always maintained by the activity of the se organis ms.

The main economical role of Actinomycetes is as a decomposer of organic matter ,help in carrying out many biochemical reactions in soil $\&$ increase the soil fertility. Numerically though they are less dominant than fungi but are potentially more active. They provide a granular \& viable structure to soil for crop production. The various antibiotics produced by Actinomycetes selectively antagonise other soil microorganisms and help in maintaining microbial equillibrium (Williams, 1978). Genus Frankia grow in nodules of non leguminous trees and fix atmospheric nitrogen (Halbe \& Nair, 2002).

Vegetative hyphae produce an extensively branched mycelium that rarely fragments. The aerial mycelium at maturity forms 3 to many spores. Initially colonies are relative ly smooth surfaced but later they develop a weft of aerial mycelium that may appear granular, powdery or velvety. They produce wide range of pigments responsible for colour of vegetative $\&$ aerial mycelium. They may form colour diffusible pigments in the medium also (Kutzner 1981). Many actinomycetes use wide range of organic compound as a sole source of carbon for ene rgy and growth at optimum te $\mathrm{mp}$ $25-35^{\circ} \mathrm{C}$, optimum $\mathrm{pH}$ range for growth at 6.5 8.0 (Pridham, 1974). The cell wall of Actinomycetes contain LL-diaminopimelic acid and DL-DAP (Lechevalie r \& Lechevalie r; 1967).

\section{Materials and Methods}

For selective isolation of Actinomycetes, treatment of soil was essential. The re fore, $1 \mathrm{gm}$ of soil was thoroughly dried at room temperature and mixed with $0.1 \mathrm{gm}$ of calcium carbonate. It was incubated for 7 days at $26^{\circ} \mathrm{C}$ in water saturated environment. This treated soil was used for dilutions in phenol water solution (phenol: water $1: 40$ ). $0.1 \mathrm{ml}$ of each dilution was used for each plate. The plates were incubated for 4-5 days.

Different media like starch-casein Agar, Inorganic salt starch Agar, MGA - SE Agar medium were used for isolation of actinomycetes and the Starch - Casein Agar and MGA-SE agar gave good results. After three days of incubation, actinomyce te colonies started appearing on the medium. They were counted from the $5^{\text {th }}$ day till 10 days. The colour and number of colonies were recorded.

Actinomycetes were identified upto the ge neric level with the help of slide \& coverslip cultures ( Walksman, 1961 ; Buchnar \& Gibson, 1975). For identification of Actinomyce tes upto 
species level physiological \& biochemical tests were carried out. They included growth on Yeast-Extract Malt Extract Agar, Glycerol aspargine agar etc. Utilization of carbon source was done using basal medium of Pridham (1974a) with different carbon sources. Colour determination was done by observation of mass colour of mature sporulating aerial surface growth, the colour of substrate mycelium as viewed from the reverse side of the plate and diffusible soluble pigments other than melanin. The substrate mycelium, colour was identified by using Special guide on actinomycetes.

The strains of pathogenic bacteria and fungi we re obtained from NCL, Pune and Department of Botany, BAMU, Aurangabad. Antagonistic tests of actinomycetes against bacteria and fungi were done using cross streak plate me thod of Huber \& Watson (1966).

\section{Results}

Actinomyctes were isolated from Rhizosphere soils of Casuarina collected from diffe re nt localities of Maharashtra. A total of 20 different actinomycetes were isolated from the rhizosphere soil of Casuarina equisetifolia L. from diffe re nt localities like Pune, Ahmednagar, Kolhapur, Ratnagiri, Dapoli. These included 14 species of Streptomyces, four species of Streptoverticillium and two unidentified Actinomycetes species. They are broadly included six different groups based on colours. i.e. grey reverse colourless, grey reverse dark, white reverse colourless, white reverse dark, pink and brown and further differentiated based on sugar utlilization, carbon source and spore chain morphology (SEM).

Seven isolates were tested for antagonism against phyto-pathogenic and human pathogenic bacteria. The pathogens used were Bacillus subtilis, Escherchia coli, Staphylococcus areus, Salmonella paratyph ̈̈ and Xanthomonas citri and Nine isolates were tested for antagonism against phyto-pathoge nic fungi Alternaria alternata, Fusarium oxysporum, Rhizoctonia solaniand Sclerotium sclerotiorum.

All the isolates tested inhibited growth of $B$. subtilis. The actinomycetes Streptomyces fervens. Streptomyces chattanoogensis and Strepto myces violaceochromogenes inhibited the growth of Bacillus subtilis and Escherchia coli (Table I). Similarly Streptomyces violaceochromogenes, Streptoverticillum fervens, Actinomycete (1) were found to be antagonistic to all studied phyto-pathogenic fungi. Phytopathogenic fungi like Alternaria alternata, Fusarium oxysporum, Rhizoctonia solani and Sclerotium sclerotiorm were sensitive to the isolates tested like Streptomyces violaceochromogenes, Streptoverticillium fervens. (Table II). These experiments clearly indicated that all actinomyce tes isolated from rhizosphere of Casuarina equiselifolia L. produced antibiotics which are mostly antagonistic to phytopathogenic fungi as well as pathogenic bacteria.

Table I - ANTAGONISM OF ACTINOMYCETES AGAINST PATHOGENIC BACTERIA

\begin{tabular}{|c|c|c|c|c|c|c|}
\hline $\begin{array}{l}\text { Sr. } \\
\text { No }\end{array}$ & Name of the Actinomycete & $\begin{array}{l}\text { Bacillus } \\
\text { subtiltis }\end{array}$ & $\begin{array}{c}\text { Escherchia } \\
\text { coli }\end{array}$ & $\begin{array}{c}\text { Xanthomonas } \\
\text { citri }\end{array}$ & $\begin{array}{c}\text { Staphyloccus } \\
\text { aureus }\end{array}$ & $\begin{array}{l}\text { Salmonella } \\
\text { paratyphii }\end{array}$ \\
\hline 1 & Streptomy ces chattanoogensis & ++ & ++ & -- & -- & -- \\
\hline 2 & $\begin{array}{l}\text { Streptomy ces } \\
\text { olivaciscieroticum }\end{array}$ & ++ & -- & ++ & -- & -- \\
\hline 3 & Streptomyces violaceochromogenes & ++ & ++ & -- & -- & -- \\
\hline 4 & Actinomycete (1) & ++ & ++ & -- & ++ & -- \\
\hline 5 & $\begin{array}{l}\text { Streptovertcillium } \\
\text { heroshemense }\end{array}$ & ++ & ++ & -- & ++ & - \\
\hline 6 & Streptomy ces fervens & ++ & ++ & -- & -- & -- \\
\hline 7 & $\begin{array}{l}\text { Streptovertcillium } \\
\text { lavenduligriseum }\end{array}$ & ++ & ++ & -- & -- & - \\
\hline
\end{tabular}

Table II- ANTAGONISM OF ACTINOMYCETES AGAINST PATHOGENIC FUNGI

\begin{tabular}{|c|c|c|c|c|c|}
\hline $\begin{array}{l}\text { Sr. } \\
\text { No }\end{array}$ & Name of the Actinomyce te & $\begin{array}{c}\text { Alternaria } \\
\text { alternata }\end{array}$ & $\begin{array}{c}\text { Fusarium } \\
\text { oxysporum }\end{array}$ & $\begin{array}{c}\text { Rhizoctonia } \\
\text { solani }\end{array}$ & $\begin{array}{c}\text { Sclerotium } \\
\text { sclerotiorum }\end{array}$ \\
\hline 1 & Streptomy ces chattanoogens is & ++ & ++ & -- & -- \\
\hline 2 & Streptomy ces olivaciscieroticum & ++ & ++ & -- & ++ \\
\hline 3 & $\begin{array}{l}\text { Streptomyces } \\
\text { violaceoch ro mogenes }\end{array}$ & ++ & ++ & ++ & ++ \\
\hline 4 & Actinomycete (1) & ++ & ++ & ++ & ++ \\
\hline 5 & $\begin{array}{l}\text { Streptovertcillium } \\
\text { heroshemense }\end{array}$ & -- & ++ & -- & -- \\
\hline 6 & Streptomyces fervens & ++ & ++ & ++ & ++ \\
\hline 7 & $\begin{array}{l}\text { Strep tovertcillium } \\
\text { lavenduligrise um }\end{array}$ & ++ & -- & -- & -- \\
\hline 8 & Streptomy ces finlayi & -- & ++ & ++ & ++ \\
\hline 9 & Streptomyces griseoruber & -- & ++ & ++ & -- \\
\hline
\end{tabular}




\section{Conclusion}

These experiments clearly indicated that the Rhizosphere soils of Casuarina equisetifolia are rich in Actinomycetes. These isolates produced antibiotics that are active against phyto-pathogenic fungi and bacteria. This ability of the Rhizosphere make the plant roots sturdy and allow them spread and grow. Thus, the actinomycetes are potential organisms for production of antibiotics.

\section{References}

Abhijit Kulkarni (2010). Colony characters and Antagonism of Streptomyces against Bacterial and fungal pathogens. Bioinfolet 7 (2): 153-155.

Bergey D.H., F.C. Harrison, R.S. Breed, B.W. Hammer and F.M. Huntoon, (1989). Bergey's manual of systematic Bacteriology, $4^{\text {th }}$ ed., The Williams and Wilkins Co., Baltimore, pp. 2451 2508.

Buchnar R.E. \& N.E.Gibson (1975). Eds. "Bergy's manual of determinative bacteriology" 8 th edn. The Williams and Wilkins Co. Baltimore.

Halbe S.C. \& L.N. Nair (2002). Actinorrhiza of Casuarina. Chapter 10-In Bioinoculants for sustainable agriculture and Forestry. Eds. S.M. Reddy et. al. Scientific Publishers, Jodhpur.

Huber D. M. and R. D. Watson (1966). Phytopathology 56: 882 .

Kutzner, H. J. (1981). The family Streptomycetaceae. In Starr et. al (eds), The Prokaryotes : A handbook on Habitat, isolation and identification of bacteria, Vol. II SpringerVerlag, Berlin, pp. 2028-2090.

Lechevalier H.H. and M.P. Lechevalier. (1967). Biology of the Actinomycetes. Ann. Rev. Microbiology 21 : 71-100. Gustav Fisher Verlag. Stuttgart.

Pridham, T.G. (1974a). Genus IV Microellobosporia. Cross et. al. In Buchnan and Gibbons (Eds), Bergey's manual of Determinative Bacteriology, $8^{\text {th }}$ ed. The Williams and Wilkins Co., Baltimore. Pp. 843-845.

Waksman S.A. (1961). "The Actinomycetes"Vol. 2. Classification, Identification and description of genera and species. The Williams and Wilkins Co. Baltimore.

Williams S.T. (1978). Streptomycetes in the soil ecosystem. In M. Mordarski et. al. (ed). Proceedings of International symposium on Nocardia and Streptomyces. Pp.137-142. 